УДК 378.1

DOI 10.18413/2712-7451-2020-39-3-443-454

\title{
Проектирование доброжелательной образовательной среды педагогического института
}

\author{
Тарабаева В.Б., Кролевецкая Е.Н. \\ Белгородский государственный национальный исследовательский университет, \\ Россия, 308015, г. Белгород, ул. Победы, 85 \\ E-mail: krolevetskaya@bsu.edu.ru
}

\begin{abstract}
Аннотация. В рамках Стратегии развития образования Белгородской области «Доброжелательная школа» на период 2019-2021 года. актуальной задачей становится подготовка «доброжелательного учителя» для «доброжелательной школы». Подготовка такого учителя с новыми профессиональными компетенциями и высокой мотивацией должна осуществляться в «доброжелательной» образовательной среде педагогического вуза. Однако указанная категория недостаточно обоснована в психолого-педагогической науке. В связи с этим авторами проведен анализ понятия «образовательная среда», раскрыта его сущность, структура. Доброжелательность образовательной среды рассмотрена как важнейшее условие, позволяющее придать образовательной среде вуза развивающий характер. Показано, что доброжелательная образовательная среда педагогического вуза является фактором формирования готовности будущего учителя к осуществлению профессиональной деятельности на основе гуманизма, сотрудничества, доброжелательности. Описан опыт разработки инициативного проекта «Доброжелательный педагогический институт НИУ «БелГУ» в рамках методологии проектного управления, проработаны такие этапы, как проблематизация, целеполагание, определение результатов проекта, требований к результату, показателей успешности проекта, разработка мероприятий проекта, определение рисков и эффектов от реализации проекта.
\end{abstract}

Ключевые слова: доброжелательная школа, образовательная среда вуза, педагогический институт, будущий учитель, проектирование, проектное управление.

Для цитирования: Тарабаева В.Б., Кролевецкая Е.Н. 2020. Проектирование доброжелательной образовательной среды педагогического института. Вопросы журналистики, педагогики, языкознания, 39 (3): 443-454. DOI 10.18413/2712-7451-2020-39-3-443-454

\section{Designing a friendly educational environment of a pedagogical institute}

\author{
Victoria B. Tarabaeva, Elena N. Krolevetskaya \\ Belgorod National Research University, \\ 85 Pobeda St, Belgorod, 308015, Russia \\ E-mail: krolevetskaya@bsu.edu.ru
}

\begin{abstract}
The idea of forming a friendly system of teacher-child relationships in the school's educational environment is a key idea of the Belgorod region's "Friendly school" education development Strategy for the period 2019-2021. Within the framework of the Strategy, an actual task is to prepare a "friendly teacher" for a "friendly school". The training of such a teacher with new professional competencies and high motivation should also be carried out in a "friendly" educational environment of a pedagogical University. However, this category is not sufficiently justified in psychological and pedagogical science. In this regard, the authors analyzed the concept of "educational environment", revealed its essence and
\end{abstract}


structure. The "goodwill" of the educational environment is considered as the most important condition that allows us to give the educational environment of the University a developing character. It is shown that the friendly educational environment of a pedagogical University is a factor in forming the readiness of a future teacher to carry out professional activities based on humanism, cooperation, and goodwill. The article describes the experience of developing the initiative project " Friendly pedagogical Institute of Belgorod National Research University" in the framework of project management methodology, such stages as problematization, goal setting, defining project results, requirements for results, indicators of project success, developing project activities, and determining the risks and effects of project implementation have been worked out.

Keywords: friendly school, educational environment of the University, pedagogical institute, future teacher, design, project management

For citation: Tarabaeva V.B., Krolevetskaya E.N. 2020. Designing a friendly educational environment of a pedagogical institute. Issues in Journalism, Education, Linguistics, 39 (3): 443-454 (in Russian).

DOI 10.18413/2712-7451-2020-39-3-443-454

\section{Введение}

Согласно стратегическим документам и инициативам, принятым на федеральном ${ }^{1}$ и региональном уровня ${ }^{2}$, современная образовательная организация должна стать тем местом, где ребёнок хочет учиться, а педагог - учить. Эта идея заложена в качестве главного ориентира в Стратегии развития образования Белгородской области «Доброжелательная школа» на период 2019-2021 года. Ключевая задача реализации Стратегии «сформировать в школе доброжелательную систему взаимоотношений педагога и ребенка, сделать ее социально-ориентированной и предметно-практической» ${ }^{3}$. «Доброжелательная школа» - это открытая образовательная среда, объединяющая всех участников образовательных отношений, основу которых составляет всесторонняя помощь, педагогическая и психологическая поддержка успешной социализации и самореализации обучающихся.

Безусловно, эта, главная, задача связана с другой, не менее важной - подготовкой «доброжелательного учителя» для «доброжелательной школы». Такой учитель «позитивен, ответственен, креативен, стремится к постоянному саморазвитию, любит детей, находит радость в общении с ними, верит в то, что каждый ребёнок может стать хорошим человеком, умеет дружить с детьми, принимает близко к сердцу детские радости и горести, знает душу ребёнка, никогда не забывает, что сам когда-то был ребенком» ${ }^{4}$. Подготовка такого учителя с новыми профессиональными компетенциями и высокой мотивацией должна, по нашей логике, также осуществляться в «доброжелательной» образовательной среде педагогического вуза.

Очевидно, что любой современный человек, находясь в стремительно и постоянно меняющихся условиях жизни, нуждается в такой «доброжелательной», психологически безопасной среде. Обеспечение безопасности образовательной среды значимо с позиций различных видов безопасности (физической [Alonso et al., 2017; Malan, Van Dijk, 2016], психологической [Баева, 2002; Коджаспиров, Коджаспирова, 2017; Подымова и др., 2018],

${ }^{1}$ Национальный проект «Образование». - URL: https://edu.gov.ru/national-project (дата обращения: 14.05.2020).

${ }^{2}$ Постановление Правительства Белгородской обл. от 20.01.2020 N 17-Пп «Об утверждении стратегии развития образования Белгородской области «Доброжелательная школа» на период 2020-2021 годы».

${ }^{3}$ Там же.

${ }^{4}$ Там же. 
социальной [Калашник, Брызгалина, 2013], информационной [Von Solms, Von Solms, 2015], экологической [Алисов, 2017] и др.), а также факторов, ее дестабилизирующих (в частности, буллинга [Glew et al., 2008; Nansel et al., 2003], насилия, притеснения, агрессии, соотнесенной с тенденциями проявления индивидуализма и коллективизма [Bergmuller, 2013] и др.).

По мнению Баевой И.А., «психологизация образовательной среды в целях сохранения и укрепления здоровья ее участников, создание безопасных условий труда и учебы в образовательной организации, защита от всех форм дискриминации могут выступать альтернативой агрессивной социальной среде, психоэмоциональному и культурному вакууму» [Баева, 2002, с. 6]. Проектирование образовательной среды, где бы личность была востребована и свободно функционировала, где бы все субъекты этой среды чувствовали защищенность и удовлетворенность основных потребностей, является важным условием функционирования «доброжелательной» школы, «доброжелательного» педагогического института. Поэтому проблема проектирования «доброжелательной» школы или «доброжелательного» педагогического вуза - это, прежде всего, проблема проектирования образовательной среды.

\section{Теоретические подходы к пониманию сущности и структуры доброжелательной образовательной среды}

Рассматривать образовательную среду можно как любое социокультурное пространство, как подсистему социокультурной среды, сочетание уже сложившихся исторических влияний, совокупность возможностей для обучения учащихся.

В зарубежных исследованиях понятие «образовательная среда» часто заменяется такими категориями, как «климат в классе», «школьная атмосфера», «культура школы» [Jafari, Asgari, 2020; Rowe et al., 2010; Urdan, Schoenfelder, 2006].

В отечественной педагогической науке образовательная среда чаще понимается как «совокупность определенных условий организации образовательного процесса» [Козырев, 2004] или «совокупность образовательных технологий, внеучебной работы, управления учебно-воспитательным процессом, взаимодействий с внешними общественными и социальными институтами» [Вачков, 2014].

Нам близок подход, связанный с изучением образовательной среды как фактора развития субъекта образования (И.А. Зимняя, Н.А. Лабунская, Т.В. Менг, С.А. Писарева, В.И. Слободчиков и др.). В данном случае образовательная среда понимается как некое пространство, в котором осуществляются социальные коммуникации и взаимодействие субъектов образования [Слободчиков, 2000], или педагогически организованное пространство, включающее социальное и предметно-пространственное окружение, систему условий, оказывающих непосредственное влияние на развитие личности [Писарева, 2005], как один из факторов, обеспечивающий её саморазвитие, включающий предпосылки для личностного развития субъектов образования, обусловленный социальным и пространственно-предметным окружением [Зимняя, 2010].

Согласно мнению Т.В. Менг, Н.А. Лабунской, «образовательная среда - это пространство социальных коммуникаций, которое вовлекает субъекта образования в процессы освоения, потребления, обмена и распространения культурных ценностей, актуализирующие его поведение» [Менг, Лабунская, 2001, с. 21].

По мнению С.В. Тарасова, «образовательная среда любого образовательного учреждения в общем виде может иметь следующие структурные компоненты:

1. Пространственно-семантический компонент:

- архитектурно-эстетическая организация жизненного пространства (архитектура здания и дизайн интерьеров, пространственная структура учебных и рекреационных по- 
мещений, возможность пространственной трансформации помещений при возникающей необходимости и др.);

- символическое пространство (различные символы - герб, гимн, традиции и др.).

2. Содержательно-методический компонент:

- содержательная сфера (концепции обучения и воспитания, образовательные и учебные программы, учебный план, учебники и учебные пособия и др.);

- формы и методы организации образования (формы организации занятий - уроки, дискуссии, конференции, экскурсии и т.д., исследовательские общества, структуры самоуправления и др.).

3. Коммуникационно-организационный компонент:

- особенности субъектов образовательной среды (распределение статусов и ролей, половозрастные и национальные особенности обучающихся и педагогов, их ценности, установки, стереотипы и т.п.);

- коммуникационная сфера (стиль общения и преподавания, пространственная и социальная плотность среди субъектов образования, степень скученности и др.);

- организационные условия (особенности управленческой культуры, наличие творческих объединений преподавателей, инициативных групп и др.)» [Тарасов, 2011].

Как отмечают А.А. Веряев, И.К. Шалаев, структура среды учреждения образования состоит из «материального, пространственно-предметного, социального и межличностного компонентов, взаимосвязанных между собой, дополняющих, обогащающих друг друга и влияющих на каждого субъекта образовательной среды. Люди, в свою очередь, также организуют, создают образовательную среду, оказывают на нее определенное воздействие» [Веряев, Шалаев, 1998].

В нашем понимании, образовательная среда педагогического института есть совокупность микросред. Под микросредой мы понимаем определенную материальную или духовную подсистему внутренней образовательной среды вуза.

Гуманистическая педагогика и психология связывают развитие личности с социальными условиями, содержащимися во взаимодействии участников образовательной среды. Образовательная среда должна обеспечивать «оптимальные показатели безопасности, соответствующие объективным условиям личностного развития ее субъектов» [Подымова и др., 2018]. Доброжелательность, или психологическая безопасность, образовательной среды является важнейшим условием, позволяющим придать образовательной среде развивающий характер.

Доброжелательная образовательная среда - это образовательная среда, «свободная от проявлений психологического насилия во взаимодействии, способствующая удовлетворению основных потребностей в личностно-доверительном общении, создающем референтную значимость среды и обеспечивающем психическое здоровье включенных в нее участников» [Баева, 2002, с. 97]

Ссылаясь на исследования М. Раудсеппа, можно сказать, что доброжелательная образовательная среда является «источником социальной поддержки с объективно позитивными эффектами (например, личностное развитие, адаптация) или субъективными эффектами (например, чувство благополучия, ответственности). Социальная поддержка включает в себя потенциальные ресурсы социальных связей, т. е. включенность субъекта в общности и группы, связи со значимыми другими». М. Раудсепп считает, что «в образовательной среде должны заключаться все пять главных типов социальной поддержки:

1. Эмоциональная поддержка: личностное доверительное общение, выражение близости, эмпатии, заботливости, понимания, симпатии, предоставление межличностного комфорта и безопасности, аффективной связи, недирективное общение.

2. Информационная поддержка: советы, анализ ситуации, обратная связь, информация, помогающая решать проблемы. 
3. Статусная поддержка: выражение принятия, одобрения, уважения, предоставление возможности для положительного социального сравнения, поддержка самоуважения субъекта, информация, нужная для самооценки, признание индивидуальности.

4. Инструментальная поддержка: услуги, материальная и практическая помощь в достижении цели, решении проблемы, преодолении кризиса и т. д.

5. Диффузная поддержка: позитивная неспецифическая интеракция, дружеское общение, совместное времяпрепровождение, отвлечение от стрессора и т. д.» [Раудсепп, 1989].

Принимая во внимание вышеизложенные точки зрения, можно отметить, что доброжелательная образовательная среда педагогического института складывается во взаимодействии образовательной инфраструктуры - набора комфортных материальных условий, в которых осуществляется образовательный процесс, и нематериальной составляющей - системы доброжелательных отношений по моделям «преподаватель - студент», «студент - студент», «студент - руководство», «преподаватель - руководство».

\section{Проектирование доброжелательной образовательной среды педагогического института}

Решение проблемы создания такой среды в педагогическом институте находится, на наш взгляд, в области педагогического проектирования. Педагогическое проектирование - это «деятельность субъектов образования, направленная на конструирование моделей преобразования педагогической действительности. Сущность педагогического проектирования состоит в выявлении и анализе педагогических проблем и причин их возникновения, построении ценностных основ и стратегий проектирования, определении целей и задач, поиске методов и средств реализации педагогического проекта» [Подымова, Алисов, 2010]. Продуктом любой проектировочной деятельности логично считать сконструированный проект ее объекта, в нашем случае - проект образовательной среды.

В качестве эффективного инструмента внедрения проекта доброжелательной образовательной среды педагогического института Белгородского государственного национального исследовательского университета нами рассматривается проектное управление.

Проектный подход в вузе - это подход к управлению, предполагающий реализацию образовательных, организационных, социальных, экономических, научных, предпринимательских и прочего рода проектов как способа решения наиболее важных для образовательной организации задач. Этот подход предназначен для дискретной деятельности, которая требует разделения на этапы. Проектная деятельность всегда ориентирована на достижение конкретной цели, результата, ограничена во времени протекания, включает уникальный комплекс работ [Москвин, 2019].

Проектное управление - это новая идеология управления образованием в России, принятая на государственном уровне ${ }^{1}$. Проектное управление можно охарактеризовать как процесс, систему, метод, в ходе которого специалисты интегрируют свои усилия, ресурсы, навыки, знания из большого количества областей, а также объединяют практический опыт, методы и инструменты управления, которые необходимы для достижения определенных целей и решения различного рода задач. Также можно определить систему проектного управления как «средство и метод для реализации целенаправленных управ-

${ }^{1}$ Постановление Правительства РФ от 15.10 .2016 № 1050 «Об организации проектной деятельности в Правительстве Российской Федерации»; Постановление Правительства от 26 декабря 2017 года № 1642 «Об утверждении государственной программы Российской Федерации "Развитие образования"» (2018-2025 гг.) 
ленческих воздействий, благодаря которым можно добиться достижения определенных задач и целей для планомерного долговременного развития социально-экономических отношений» [Гурьянова, 2012].

Система высшего образования сегодня широко использует проектное управление благодаря ряду преимуществ. Во-первых, проектное управление способствует улучшению различных показателей, как количественных, так и качественных. Благодаря этому происходит сокращение сроков реализации проекта, достигается получение требуемых характеристик результатов, что является эффективным для будущего развития. Во-вторых, проектное управление является удобным инструментом управления, так как «сочетает в себе наличие всей необходимой актуальной информации, которую можно получить в любое время и в любом месте, а также наличие определенных закрепленных процессов взаимодействия между участниками» [Муравьева, Лебедева, 2019].

Таким образом, методология проектного управления явилась базовым основанием для разработки инициативного проекта «Доброжелательный педагогический институт НИУ «БелГУ».

Создание проекта предполагало следующие этапы: проблематизация, целеполагание, определение результатов проекта, требований к результату, показателей успешности проекта, разработка мероприятий проекта, расчет бюджета проекта, определение рисков и эффектов от реализации проекта.

Разработка проекта началась с этапа проблематизации - это аналитический процесс работы в проблемном поле с целью выделения проблемы или ряда проблем для последующего их рассмотрения и решения.

Анализируя идею проекта и соотнося ее с реальными потребностями субъектов образования конкретного вуза, мы приняли решение изучить уровень «доброжелательности» компонентов образовательной среды педагогического института. Среди студентов 13 курса педагогического института НИУ «БелГУ» был проведен опрос, в котором требовалось оценить, какой из компонентов образовательной среды кажется студентам «доброжелательным» по отношению к ним, а какой - нет.

Студенты оценивали следующие компоненты (или микросреды) образовательной среды педагогического института НИУ «БелГУ»: материально-пространственная микросреда (материально-техническая база института); информационная микросреда (информационные ресурсы, библиотечные фонды); цифровая образовательная микросреда (система электронного обучения «Пегас»); здоровьесберегающая микросреда (медицинские, спортивные объекты и подразделения); воспитательная микросреда (воспитательные центры, творческие объединения, система воспитательных мероприятий); микросреда инклюзивного образования (специализированные объекты, оборудование); микросреда отношений «преподаватель-студент».

Результаты исследования (рис. 1) показали, что большинство студентов удовлетворены такими микросредами педагогического института НИУ «БелГУ», как материальнопространственная (98\%), информационная (96\%), цифровая (86 \%), здоровьесберегающая (84\%), воспитательная микросреда (72\%). Взаимодействие в рамках этих микросред они оценили как комфортное, удобное, понятное, безопасное. Однако лишь 32 \% студентов оценили систему отношений «преподаватель - студент» как доброжелательную. Студенты отметили, что именно с этой подсистемой в большей степени ассоциируется у них понятие «доброжелательная среда педагогического института». Проблемы во взаимодействии с преподавателями воспринимаются студентами как наиболее важные, значимые, базово влияющие на чувство комфорта и защищенности в образовательной среде, и, как следствие, на успешность их личностного и профессионального развития. 


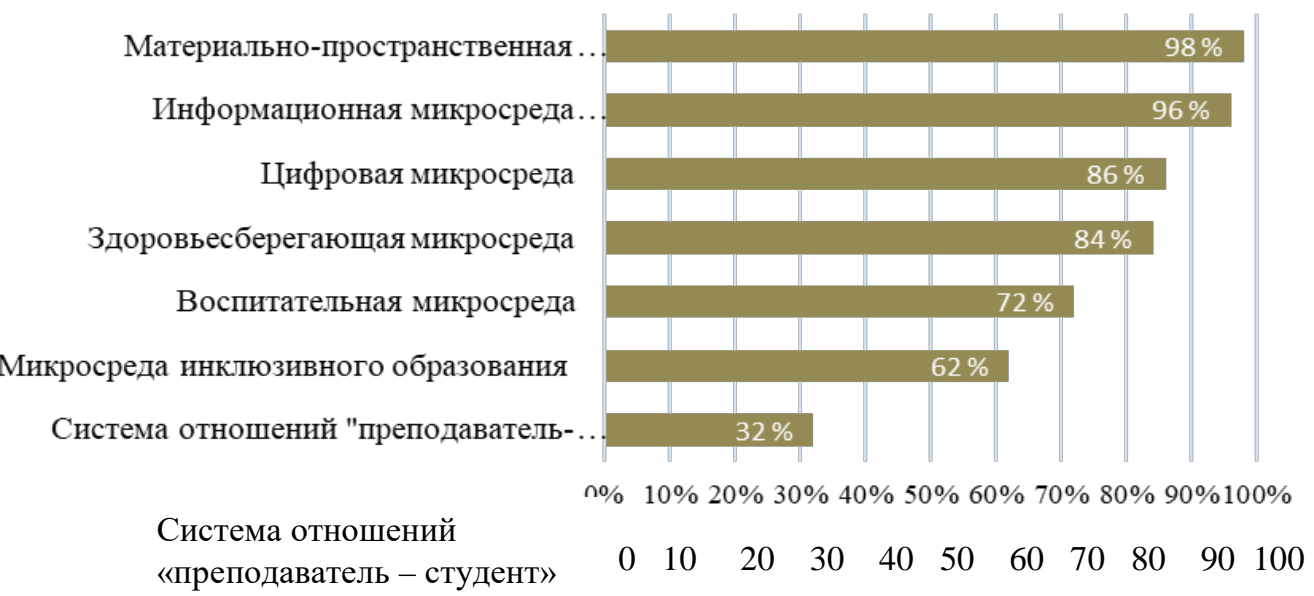

Рис. 1. Оценка уровня «доброжелательности» компонентов образовательной среды педагогического института студентами педагогического института НИУ «БелГУ»

Fig. 1. Assessment of the level of "goodwill" of the components of the educational environment of the pedagogical institute by students of the pedagogical institute of the Belgorod National Research University

Дальнейший анализ позволил детализировать круг проблем в системе отношений «преподаватель - студент» (рис. 2).

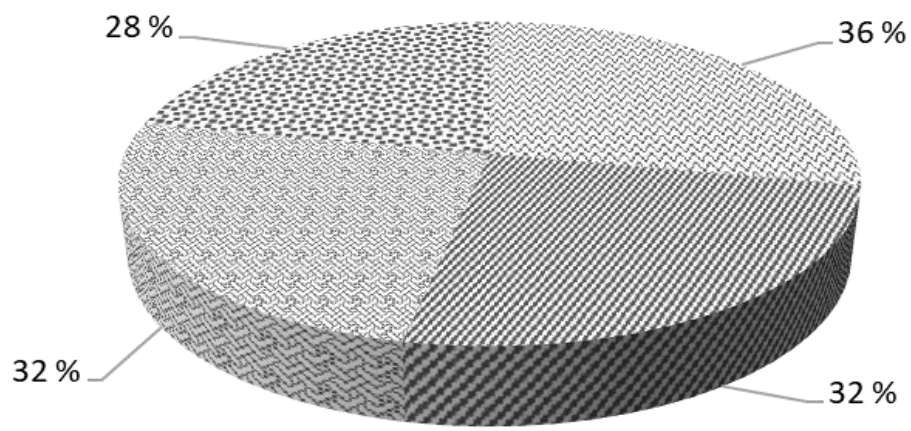

\footnotetext{
$\approx$ Проблема готовности преподавателей педагогического института к реализации "доброжелательных" психолого-педагогических технологий

乡 Проблема снижения контактного времени взаимодействия преподавателя и студентов

ॠ Проблема доброжелательности молодых преподавателей педагогического института

зг Проблема поддержки индивидуальных педагогических интересов и талантов студентов
}

Рис. 2. Выявленные проблемы в системе отношений «преподаватель-студент»

Fig. 2. Identified problems in the system of relations «teacher-student»

Опрос студентов и экспертная оценка показали, что проблемное поле педагогического проектирования могут составлять следующие аспекты:

- недостаточная готовность профессорско-преподавательского состава к реализации доброжелательных педагогических технологий, инновационных образовательных практик; 
- недостаточная эффективность контактного времени взаимодействия преподавателя и студентов;

- снижение ценности доброжелательности у молодых преподавателей;

- недостаточная поддержка индивидуальных педагогических интересов и талантов студентов.

Необходимость решения указанных проблем определила целевые ориентиры инициативного проекта «Доброжелательный педагогический институт НИУ «БелГУ».

Методология проектного управления позволила сформулировать цели проекта, соответствующие критериям SMART [Doran, 1981]:

1. Подготовить не менее, чем 80 \% профессорско-преподавательского состава педагогического института НИУ «БелГУ» к использованию доброжелательных психологопедагогических технологий в образовательном процессе к 01.12.2020.

2. Обеспечить участие не менее, чем 70 \% студентов педагогического института НИУ «БелГУ» в студенческих конкурсах, олимпиадах, дополнительных программах профессионального обучения, развивающих индивидуальные педагогические таланты и интересы студентов, к 01.12.2020.

Достижение целей осуществимо через разработку и реализацию системы мероприятий по развитию «доброжелательных» психолого-педагогических компетенций у профессорско-преподавательского состава, проведение педагогических и психологических конкурсов, олимпиад, обучения по дополнительным программам профессионального обучения для студентов педагогического института.

В рамках основных блоков работ по проекту в течение 2020 года запланировано поведение следующих мероприятий:

- диагностика готовности профессорско-преподавательского состава к реализации доброжелательных педагогических технологий;

- подготовка преподавателей педагогического института НИУ «БелГУ» к использованию доброжелательных педагогических технологий, инновационных образовательных практик с применением онлайн-технологий (обучение по программе повышения квалификации «Современные аспекты преподавания в вузе: доброжелательные психологопедагогические технологии»);

- проведение всероссийской научно-практической конференции «Доброжелательное образовательное пространство: инновационные практики школы и вуза»;

- организация Летней школы доброжелательности для молодых преподавателей, кураторов, тьюторов педагогического института НИУ «БелГУ» («Интенсив доброжелательности»);

- психологическое сопровождение взаимодействия преподавателя и студентов (социально-психологические тренинги доброжелательного педагогического общения, мастер-классы, дискуссионный клуб «Психология доброжелательности»);

- проведение региональной педагогической олимпиады «Наша доброжелательная школа», конкурса студенческих эссе, программ профессионального обучения.

Разработанные в рамках проекта мероприятия позволят, на наш взгляд, осуществить следующее:

- создание комфортной среды для обмена лучшими образовательными практиками;

- совершенствование системы повышения квалификации профессорскопедагогического состава педагогического института в области доброжелательных педагогических технологий;

- психологическое сопровождение профессиональной деятельности преподавателя вуза;

- увеличение эффективности контактного времени взаимодействия преподавателя и студентов за счет социально-психологических тренингов доброжелательного педагогического общения, работы дискуссионного клуба «Психология доброжелательности»; 
- создание условий для осознания молодыми преподавателями педагогического института стратегии доброжелательной образовательной среды и принятия ценности доброжелательности;

- создание условий для выявления талантливых студентов и развития их одаренности через систему студенческих конкурсов, олимпиад;

- увеличение охвата обучающихся дополнительными программами профессионального обучения.

Главными эффектами от реализации инициативного проекта, на наш взгляд, станут повышение качества образовательного процесса за счет положительной динамики использования доброжелательных педагогических технологий, инновационных образовательных практик, а также создание системы психологического сопровождения профессиональной деятельности преподавателя вуза.

\section{Заключение}

Таким образом, проектирование доброжелательной образовательной среды педагогического института является фактором формирования готовности будущего учителя к осуществлению профессиональной педагогической деятельности на основе гуманизма, сотрудничества, доброжелательности. Такая среда стимулирует активность и самостоятельность будущего учителя в процессе творческой деятельности; выступает пространством для социально и профессионально значимой деятельности будущего педагога; гарантирует возможность комфортного, безопасного существования субъектов в образовательном пространстве; способствует осуществлению совместной продуктивной деятельности, конструктивному взаимодействию в процессе образования.

Инструментом разработки инициативного проекта «Доброжелательный педагогический институт НИУ «БелГУ» явилось проектное управление, которое всегда ориентировано на достижение конкретной цели, результата, ограничено во времени протекания, включает уникальный комплекс работ. Этап проблематизации выявил круг проблем в системе отношений «преподаватель - студент» и позволил определить целевые ориентиры проекта, связанные с развитием «доброжелательных» психолого-педагогических компетенций у профессорско-преподавательского состава педагогического института.

Разработанные в рамках проекта мероприятия позволят достичь конкретных результатов, связанных с созданием комфортной среды для обмена лучшими образовательными практиками, психологическим сопровождением профессиональной деятельности преподавателей, увеличением эффективности контактного времени взаимодействия преподавателя и студентов, созданием условий для принятия субъектами образовательной среды ценности доброжелательности.

\section{Список источников}

1. Зимняя И.А. 2010. Педагогическая психология. Под ред. И.А. Зимней. Москва, Издательство Московского психолого-социального института; Воронеж, МОДЭК, 448 с.

2. Коджаспиров А.Ю., Коджаспирова Г.М. 2017. Психолого-педагогическая безопасность образовательной среды детских учреждений. М., Проспект, 464 с. URL: https://rucont.ru/efd/632755 (дата обращения: 07.04.2020).

3. Москвин С.Н. 2019. Управление проектами в сфере образования. Под ред. C.Н. Моквина. Москва, Юрайт, 139 с. URL: https://urait.ru/bcode/446191 (дата обращения: 04.04.2020).

4. Писарева С.А. 2005. Образовательная среда профильного обучения. Под ред. А.П. Тряпицыной. СПб., КАРО, 96 с.

\section{Список литературы}

1. Алисов Е.А. 2016. Категориальная специфика понятия «Экологически безопасная образовательная среда». В кн.: Современное образование в стране: состояние, проблемы, перспективы развития. Сборник материалов городского межвузовского Круглого стола, Москва, 7- 
9 октября 2016 года. Под ред. Л.В. Поляковой, Г.М. Коджаспировой. М., Издательство «ЭконИнформ»: 3-7.

2. Баева И.А. 2002. Психологическая безопасность в образовании. Под ред. И.А. Баевой. СПб., Издательство «СОЮЗ», $271 \mathrm{c.}$

3. Вачков И.В. 2014. Полисубъектное взаимодействие в образовательной среде. Психология. Журнал Высшей школы экономики, 11 (2): 36-50.

4. Веряев А.А., Шалаев И.К. 1998. От образовательных сред к образовательному пространству: понятие, формирование, свойства. Педагог: наука, технология, практика. 1 (4): 33- 39.

5. Гурьянова Э.А., Зайнуллина М.Р., Мещерякова С.А., Набиева Л.Г., Новикова Е.Н., Палей Т.Ф., Ревкова Е.Г. 2012. Реализация проектно-ориентированной модели управления в сфере высшего профессионального образования. Казань, Издательство Института экономики и финансов К(П)ФУ, 160 c.

6. Кашник О.И., Брызгалина А.А. 2013. Социальная безопасность: теоретические аспекты. Образование и наука, 3 (102): 98-110. DOI: https://doi.org/10.17853/1994-5639-2013-3-98-110.

7. Козырев В.А. 2004. Гуманитарная образовательная среда педагогического университета: сущность, модель, проектирование. Под ред. В.А. Козырева. СПб., Изд-во РГПУ им. А.И. Герцена, 328 с.

8. Менг Т.В., Лабунская Н.А. 2001. Образовательная среда: подходы к раскрытию понятия. В кн.: Образовательная среда школы: проблемы и перспективы развития. Материалы шестой научно-практической конференции, Санкт-Петербург, 15 февраля 2001 года. СПб., Издательство Образование: 19-21.

9. Муравьева Н.Н. Лебедева А.М. 2019. Проектное управление в сфере образования. Журнал "У". Экономика. Управление. Финансы, 2: 113-119. URL: https://portalu.ru/index.php/journal/article/view/217 (дата обращения: 03.04.2020).

10. Подымова Л.С., Алисов Е.А. 2010. Готовность субъектов образовательного процесса к педагогическому проектированию образовательной среды. Вестник Тамбовского университета. Серия: Гуманитарные науки, 12 (92): 135-138.

11. Подымова Л.С., Подымов Н.А., Алисов Е.А. 2018. Готовность педагогов к обеспечению безопасности личности в инновационной образовательной среде. Интеграция образования, т. 22, № 4 (93): 663-680. DOI: 10.15507/1991-9468.093.022.201804.663-680.

12. Раудсепп М. 1989. Субъект и поддерживающая среда. В кн.: Средовые условия развития социальных общностей. Под ред. Т. Нийта. Таллин: 67-92.

13. Слободчиков В.И. 2000. О понятии образовательной среды в концепции развивающего образования. Под ред. В.И. Слободчикова. М., Экопсицентр РОСС, 230 с.

14. Тарасов С.В. 2011. Образовательная среда: понятие, структура, типология. Вестник ЛГУ им. А.С. Пушкина, 3 (3): 133-138.

15. Alonso F., Esteban C., Tortosa F., Useche S. 2017. Perception of Road Safety in Children's Environment. American Journal of Educational Research, 5 (3): 273-278. DOI: 10.12691/education-5-3-7.

16. Bergmuller S. 2013. The relationship between cultural individualism-collectivism and student aggression across 62 countries. Agressive Behavior, 39 (3): 182-200. DOI: 10.1002/ab.21472.

17. Doran G.T. 1981. There's a S.M.A.R.T. Way to Write Management's Goals and Objectives. Management Review, Volume 70 (11): 35-36.

18. Glew G.M., Fan M.-Yu, Katon W., Rivara F.P. 2008. Bulling and school safety. The Journal of Pediatrics, 152 (1): 123-128. DOI: 10.1016/j.jpeds.2007.05.045.

19. Jafari S., Asgari A. 2020. Predicting Students' Academic Achievement Based on the Classroom Climate, Mediating Role of Teacher-Student Interaction and Academic Motivation. Integration of Education, 24 (1): 62-74. DOI: https://doi.org/10.15507/19919468.098.024.202001.062-074 ((in Russian).

20. Malan L., Van Dijk D. 2016. The strategy to align road safety education to the further education and training band curriculum. Africa Education Research, 13: 132-146. DOI: 10.1080/18146627.2016.1224557.

21. Nansel T.R., Overpeck M.D., Haynie D.L., Ruan W.J., Scheidt P.C. 2003. Relationships between bullying and violence among US youth. Archives of Pediatrics \& Adolescent Medicine, 157(4):348-353. DOI: 10.1001/archpedi.157.4.348. 
22. Rowe E.W., Kim S., Baker J.A., Kamphaus R.W., Horne A.M. 2010. Student Personal Perception of Classroom Climate: Exploratory and Confirmatory Factor Analyses. Educational and Psychological Measurement, 70 (5): 858-879. Available at: https://eric.ed.gov/?id=EJ898768 (accessed: 03.03.2020).

23. Urdan T., Schoenfelder E. 2006. Classroom Effects on Student Motivation: Goal Structures, Social Relationships, and Competence Beliefs. Journal of School Psychology, 44 (5): 331-349. DOI: https://doi.org/10.1016/j.jsp.2006.04.003.

24. Von Solms R., Von Solms S. 2015. Cyber Safety Education in Developing Countries. Systemics, Cybernetics and Informatics, 13 (2): 14-19. Available at: https://pdfs.semanticscholar.org/7841/32717d6cb981e654b579d1285339a554ea7b.pdf ） (accessed: 03.03.2020).

\section{References}

1. Alisov E.A. 2016. Kategorial'naya spetsifika ponyatiya «Ekologicheski bezopasnaya obrazovatel'naya sreda» [Categorical specificity of the concept "Environmentally safe educational environment"]. In: Sovremennoe obrazovanie v strane: sostoyanie, problemy, perspektivy razvitiya [Modern education in the country: state, problems, development prospects]. Collection of materials of the city interuniversity Round table, Moscow, October 7-9, 2016. Eds. L.V. Polyakova, G.M. Kodzhaspirova. M., Publ. Izdatel'stvo «Ekon-Inform»: 3-7.

2. Baeva I.A. 2002. Psikhologicheskaya bezopasnost' v obrazovanii [Psychological safety in education]. Ed. I.A. Baeva. SPb., Publ. Izdatel'stvo «SOYuZ», 271 p.

3. Vachkov I.V. 2014. Polisub"ektnoe vzaimodeystvie v obrazovatel'noy srede [Polysubject interaction in the educational environment]. Psychology. Journal of the Higher School of Economics, 11 (2): $36-50$.

4. Veryaev A.A., Shalaev I.K. 1998. Ot obrazovatel'nykh sred k obrazovatel'nomu prostranstvu: ponyatie, formirovanie, svoystva [From educational environments to educational space: concept, formation, properties]. Pedagog: nauka, tekhnologiya, praktika, 1 (4): 33-39.

5. Gur'yanova E.A., Zaynullina M.R., Meshcheryakova S.A., Nabieva L.G., Novikova E.N., Paley T.F., Revkova E.G. 2012. Realizatsiya proektno-orientirovannoy modeli upravleniya v sfere vysshego professional'nogo obrazovaniya [Implementation of a project-oriented management model in higher education]. Kazan', Publ. Izdatel'stvo Instituta ekonomiki i finansov K(P)FU, 160 p.

6. Kashnik O.I., Bryzgalina A.A. 2013. Sotsial'naya bezopasnost': teoreticheskie aspekty [Social security: theoretical aspects]. The Education and Science Journal, 3 (102): 98-110. DOI: https://doi.org/10.17853/1994-5639-2013-3-98-110.

7. Kozyrev V.A. 2004. Gumanitarnaya obrazovatel'naya sreda pedagogicheskogo universiteta: sushchnost', model', proektirovanie [Humanitarian educational environment of a pedagogical university: essence, model, design]. Ed. V.A. Kozyrev. SPb., Publ. Izd-vo RGPU im. A.I. Gertsena, 328 p.

8. Meng T.V., Labunskaya N.A. 2001. Obrazovatel'naya sreda: podkhody k raskrytiyu ponyatiya [Educational environment: approaches to the disclosure of the concept]. In: Obrazovatel'naya sreda shkoly: problemy i perspektivy razvitiya [The educational environment of the school: problems and development prospects]. Materialy shestoy nauchno-prakticheskoy konferentsii, Sankt-Peterburg, 15 fevralya 2001 goda. SPb., Publ. Izdatel'stvo Obrazovanie: 19-21.

9. Murav'eva N.N. Lebedeva A.M. 2019. Proektnoe upravlenie v sfere obrazovaniya [Project management in the sphere of education]. Journal "U". Economy. Management. Finance, 2: 113-119. Available at: https://portal-u.ru/index.php/journal/article/view/217 (accessed: 03.04.2020).

10. Podymova L.S., Alisov E.A. 2010. Gotovnost' sub"ektov obrazovatel'nogo protsessa k pedagogicheskomu proektirovaniyu obrazovatel'noy sredy [Readiness of the subjects of the educational process for the pedagogical design of the educational environment]. Tambov University Review. Series: Humanities, 12 (92): 135-138.

11. Podymova L.S., Podymov N.A., Alisov E.A. 2018. Gotovnost' pedagogov k obespecheniyu bezopasnosti lichnosti $\mathrm{v}$ innovatsionnoy obrazovatel'noy srede [The readiness of teachers to ensure personal safety in an innovative educational environment]. Integration of Education, Vol. 22, No. 4 (93): 663-680. DOI: 10.15507/1991-9468.093.022.201804.663-680.

12. Raudsepp M. 1989. Sub"ekt i podderzhivayushchaya sreda [Subject and supportive environment]. In.: Sredovye usloviya razvitiya sotsial'nykh obshchnostei. [Environmental conditions for the development of social communities.]. Ed. T. Niyta. Tallin: 67-92. 
13. Slobodchikov V.I. 2000. O ponyatii obrazovatel'noy sredy v kontseptsii razvivayushchego obrazovaniya [On the concept of the educational environment in the concept of developing education]. Ed. V.I. Slobodchikov. M., Publ. Ekopsitsentr ROSS, 230 p.

14. Tarasov S.V. 2011. Obrazovatel'naya sreda: ponyatie, struktura, tipologiya [Educational environment: concept, structure, typology]. Vestnik of Pushkin Leningrad State University, 3 (3): 133-138.

15. Alonso F., Esteban C., Tortosa F., Useche S. 2017. Perception of Road Safety in Children's Environment. American Journal of Educational Research, 5 (3): 273-278. DOI: 10.12691/education-5-3-7.

16. Bergmuller S. 2013. The relationship between cultural individualism-collectivism and student aggression across 62 countries. Agressive Behavior, 39 (3): 182-200. DOI: 10.1002/ab.21472.

17. Doran G.T. 1981. There's a S.M.A.R.T. Way to Write Management's Goals and Objectives. Management Review, Volume 70 (11): 35-36.

18. Glew G.M., Fan M.-Yu, Katon W., Rivara F.P. 2008. Bulling and school safety. The Journal of Pediatrics, 152 (1): 123-128. DOI: 10.1016/j.jpeds.2007.05.045.

19. Jafari S., Asgari A. 2020. Predicting Students' Academic Achievement Based on the Classroom Climate, Mediating Role of Teacher-Student Interaction and Academic Motivation. Integration of Education, 24 (1): 62-74. DOI: https://doi.org/10.15507/1991-9468.098.024.202001.062074 ((in Russian).

20. Malan L., Van Dijk D. 2016. The strategy to align road safety education to the further education and training band curriculum. Africa Education Research, 13: 132-146. DOI: 10.1080/18146627.2016.1224557.

21. Nansel T.R., Overpeck M.D., Haynie D.L., Ruan W.J., Scheidt P.C. 2003. Relationships between bullying and violence among US youth. Archives of Pediatrics \& Adolescent Medicine, 157(4):348-353. DOI: 10.1001/archpedi.157.4.348.

22. Rowe E.W., Kim S., Baker J.A., Kamphaus R.W., Horne A.M. 2010. Student Personal Perception of Classroom Climate: Exploratory and Confirmatory Factor Analyses. Educational and Psychological Measurement, 70 (5): 858-879. Available at: https://eric.ed.gov/?id=EJ898768 (accessed: 03.03.2020).

23. Urdan T., Schoenfelder E. 2006. Classroom Effects on Student Motivation: Goal Structures, Social Relationships, and Competence Beliefs. Journal of School Psychology, 44 (5): 331-349. DOI: https://doi.org/10.1016/j.jsp.2006.04.003.

24. Von Solms R., Von Solms S. 2015. Cyber Safety Education in Developing Countries. Systemics, Cybernetics and Informatics, 13 (2): 14-19. Available at: https://pdfs. semanticscholar.org/7841/32717d6cb981e654b579d1285339a554ea7b.pdf (accessed: 03.03.2020).

\section{ИНФОРМАЦИЯ ОБ АВТОРАХ}

Тарабаева Виктория Борисовна, доктор социологических наук, профессор, профессор кафедры психологии педагогического института, директор педагогического института Белгородского государственного национального исследовательского университета, г. Белгород, Россия

Кролевецкая Елена Николаевна, кандидат педагогических наук, доцент, доцент кафедры педагогики педагогического института Белгородского государственного национального исследовательского университета, г. Белгород, Россия

\section{INFORMATION ABOUT THE AUTHORS}

Victoria B. Tarabaeva, Doctor of Sociological Sciences, Professor, Professor of the Department of Psychology of the Pedagogical Institute, Director of the Pedagogical Institute, Belgorod State National Research University, Belgorod, Russia

Elena N. Krolevetskaya, Candidate of Pedagogical Sciences, Associate Professor, Associate Professor of the Pedagogy Department of the Pedagogical Institute, Belgorod State National Research University, Belgorod, Russia 